Н. О. Мельник, Г. Ю. Кондаурова

Національний медичний університет імені О. О. Богомольця, м. Київ

\title{
ОСОБЛИВОСТІ КОНТРОЛЮ ЗНАНЬ СТУДЕНТІВ-ІНОЗЕМЦІВ АНГЛОМОВНОЇ ФОРМИ НАВЧАННЯ ЗА ДОПОМОГОЮ ТЕСТОВИХ ЗАВДАНЬ НА КАФЕДРІ ГІСТОЛОГІЇ ТА ЕМБРІОЛОГІЇ НАЦІОНАЛЬНОГО МЕДИЧНОГО УНІВЕРСИТЕТУ ІМЕНІ О. О. БОГОМОЛЬЦЯ
}

\author{
N. O. Melnyk, H. Yu. Kondaurova \\ O. Bohomolets National Medical University, Kyiv \\ PECULIARITIES OF KNOWLEDGE CONTROL FOR FOREIGN \\ STUDENTS OF ENGLISH FORM OF EDUCATION BY MEANS OF \\ THE TEST PROBLEMS ON THE HISTOLOGY AND EMBRYOLOGY \\ DEPARTMENT IN O. BOHOMOLETS NATIONAL \\ MEDICAL UNIVERSITY
}

\begin{abstract}
Мета роботи - аналіз досвіду використання тестових завдань в іноземних англомовних студентів на кафедрі гістології та ембріології Національного медичного університету імені О. О. Богомольця.

Основна частина. 3 метою стандартизації оцінки знань студентів на кафедрі для студентів англомовної форми навчання використовуються тестові завдання, складені за типом ліцензійного іспиту “Крок 1”. Тести розподілені за такими розділами, як: цитологія, ембріологія, загальна гістологія та спеціальна гістологія, а в кожному розділі - згідно з темами календарнотематичного плану. На кожному занятті студент повинен відповісти на десять питань, тим самим всі тестові завдання уніфіковані за ваговою складовою при розрахунку результатів оцінювання за конкретну тему. Тестування дає можливість не тільки урізноманітнити процес діагностики рівня підготовки студентів, а й об’єктивно отримати реальну картину засвоєння знань та навичок. Тестовий контроль забезпечує одночасну перевірку знань студентів і формує мотивацію регулярно готуватися до кожного заняття, дисциплінує їх. До вагомих переваг тестового контролю потрібно віднести об’єктивність та справедливість оцінки знань, які зменшують емоційні перевантаження студентів, забезпечують прозорість і відкритість результатів контролю, розвивають індивідуально-диференційований підхід до навчання та самостійної роботи студентів.

Висновки. Система тестів дозволяє швидко оцінити рівень знань студентів на занятті за короткий термін часу, перейти до виконання практичної роботи. Тестова перевірка знань - вдала форма закріплення, осмислення, систематизації матеріалу.
\end{abstract}

Ключові слова: тестовий контроль; англомовна форма навчання; кафедра гістології.

The aim of the work - analysis of the experience of using the test tasks in foreign English-speaking students at the Department of Histology and Embryology of O. Bohomolets National Medical University.

The main body. In order to standardize the assessment of students' knowledge, the test assignments, compiled according to the type of license test Krok-1, are used at the department. The tests are divided by sections: cytology, embryology, general histology and special histology, and in each section - according to the themes of the calendar-thematic plan. In all classes, students have to answer for ten questions, thus all standardized tests for weight component in calculating the results of the assessment on a particular theme. Testing gives an opportunity not only to diversify the process of diagnosing the level of students' knowledge, but also to objectively obtain a realistic picture of the acquisition of knowledge and skills. Test control provides simultaneous examination of students' knowledge and forms the motivation to regularly prepare for each class, disciplines them. The important advantages of test control include the objectivity and fairness of knowledge assessment, which reduces students' emotional overload, provide transparency and openness to the results of control, develop an individually differentiated approach to learning and independent work of students.

Conclusions. Thus, the system of tests allows you to quickly assess the level of knowledge of students in the classroom in a short time, go to the implementation of practical work. Testing of knowledge is a successful form of consolidation, comprehension, systematization of the material.

Key words: test control; the English-language form of education; the department of histology. 
Вступ. Завдяки тенденції до євроінтеграції, обміну досвідом, продовження післядипломної освіти у країнах Європи та США значно зросла кількість студентів, що воліють навчатись англійською мовою, i, при цьому, отримати гідну якість освіти.

Процес навчання у ВНЗ України медичного напрямку достатньо складний. Студенти стикаються 3 низкою проблем: недостатнім володінням англійською мовою, слабкою підготовкою за профільними та спеціальними дисциплінами, відсутністю навичок самостійної роботи, несформованим алгоритмом використання на практичних заняттях теоретичного матеріалу і відчутною різницею між формами та методами навчання в університетах України й у вищій школі на власній батьківщині [1].

На відміну від звичайного студента, на рівень навчання англомовного іноземного студента впливає ряд факторів, таких, як: особливості сприйняття того чи іншого матеріалу, мовні труднощі, вік, рівень довузівської підготовки, сімейний стан, володіння навиками самоорганізації, планування і контролю своєї діяльності (перш за все навчальної); мотиви вибору вузу; адекватність вихідних уявлень про специфіку навчання у вищому медичному закладі.

Велике значення мають такі фактори, як: рівень інтелекту, індивідуальні психологічні особливості, креативність, навчальна мотивація, що забезпечує позитивні переживання при досягненні навчальних цілей, висока самооцінка, яка приводить до формування високого рівня вимог, організація навчального процесу у вищому навчальному закладі, рівень кваліфікації викладачів, престижність медичного університету. Викладачі, які працюють зі студентами іноземцями англомовної форми навчання (АФН), мають всяко заохочувати студентів до навчання та підтримувати їх бажання максимально засвоювати теоретичний матеріал і практичні навички. Крім того, навчальний план для іноземних студентів не має бути перевантажений зайвою інформацією, та повинен легко сприйматися [1, 2].

У зв’язку з цим перед викладачем постають певні проблеми з організацією навчального процесу. Особливо це стосується молодших доклінічних курсів, коли студенти ще мало адаптовані до проживання на території України.

Мета роботи - аналіз досвіду використання тестових завдань в іноземних англомовних студентів на кафедрі гістології та ембріології Національного медичного університету імені О. О. Богомольця.
Основна частина. Навчання у вищих медичних закладах має більш ділову спрямованість, бо кожен навчальний предмет орієнтує студентів-медиків на майбутню професійну діяльність, готує їх до виконання фахових функцій медика, оволодіння необхідними для цього знаннями, уміннями та навичками в медицині. Навчання у вищій медичній школі - це процес складний і важкий, який вимагає від студентів високого рівня самосвідомості й активності, самоорганізації, надзвичайно великого інтелектуального напруження, зосередженості уваги, раціонального розподілу часу на роботу і відпочинок.

Не варто забувати про високу навчальну завантаженість студентів першого курсу. Через це обмеженість у часі і невміння першокурсників самостійно працювати 3 навчальним матеріалом, а також складність засвоєння окремих дисциплін у медичних вищих навчальних закладах призводять до зниження академічної активності студентів, а отже, успішності і якості знань.

Активізація професійної мотивації студентів вищих навчальних закладів залежить від цілого комплексу чинників, серед яких: можливості життєзабезпечення та особистісного розвитку; впровадження викладачами вищих навчальних закладів інноваційних підходів у навчанні; активність соціальних контактів, їх розширення та збагачення; оптимізація міжособистісної різнорівневої взаємодії; можливості професійного становлення.

На сьогодні умови та засоби навчання для студентів досить широкі - це наукова література, підручники, методичні посібники, Інтернет і мультимедійні засоби, лабораторне обладнання і технічні засоби навчання, що дає змогу студентам краще засвоювати матеріал.

Дисципліна "Гістологія, цитологія, ембріологія" входить до складу базових дисциплін i, тому, є важливою не тільки з точки зору отримання конкретних теоретичних і практичних знань, а й формування навичок до самостійної роботи, а в подальшому мотивації до постійної самоосвіти.

Англомовні студенти мають достатню кількість навчально-методичних посібників з предмета, також вони можуть отримати консультативну допомогу викладача, все це надає можливість краще підготуватися до заняття.

Лектори наполегливо працюють над обранням оптимальної форми подання матеріалу для кращого засвоєння студентами лекційного матеріалу: у вигляді схем, навчальних слайдів, графологічних 
структур, рисунків, та мультимедійних презентацій. Варто зазначити, що з 2017-2018 навчального року у НМУ імені О. О. Богомольця введений особливий формат подання лекційного матеріалу - 45 хвилин, що сприяє кращому запам'ятовуванню і сприйняттю матеріалу. На кафедрі гістології та ембріології під час практичного заняття проводиться комплексний контроль знань шляхом усного опитування, оцінювання виконання практичної роботи та вміння аналізувати гістологічні препарати.

3 метою стандартизації оцінки знань студентів на кафедрі для студентів англомовної форми навчання використовуються тестові завдання, складені за типом ліцензійного іспиту “Крок 1”. Тести розподілені за такими розділами, як: цитологія, ембріологія, загальна гістологія та спеціальна гістологія, а в кожному розділі - згідно з темами календарно-тематичного плану. На кожному занятті студент повинен відповісти на десять питань, тим самим всі тестові завдання уніфіковані за ваговою складовою при розрахунку результатів оцінювання за конкретну тему. Тестування дає можливість не тільки урізноманітнити процес діагностики рівня підготовки студентів, а й об’єктивно отримати реальну картину засвоєння знань та навичок.

Питання в тестових завданнях сформульовані як ситуаційна задача. Це дозволяє студентам, починаючи з перших курсів, розвинути клінічне мислення. Кожне питання має п’ять можливих варіантів відповіді, одна з яких - правильна. Робота з тестовими завданнями займає до 15 хвилин часу. Після перевірки відповідей студентів найбільш складні питання, на думку самих студентів, розбираються усно з викладачем. При цьому важливо навчити студентів аргументувати правильність однієї відповіді і неправильність інших. Завдяки аналізу помилок студентів при вирішенні тестових завдань викладачеві легше зрозуміти, які саме питання практичного заняття вимагають більш детального розбору.

Перевірка й оцінювання знань та вмінь студентів $є$ важливою складовою навчання. Результатом контролю є показник співвідношення між поставленою метою навчання і досягнутими результатами. Процес контролю - це одна з найбільш трудомістких і відповідальних операцій, пов’язана з гострими психологічними ситуаціями як для студентів, так і для викладача. 3 іншого боку, його правильна постановка сприяє поліпшенню якості підготовки фахівців.

Тестування як форма контролю та діагностики знань студентів набуває все більшого розповсюдження в навчальному процесі, оскільки має певні переваги над іншими формами контролю знань та вмінь, зокрема можливість охоплення великого обсягу матеріалу [3].

Тестова перевірка знань має цілу низку переваг перед традиційними формами і методами та гармонійно вписується в сучасну педагогічну концепцію. Вона дозволяє раціонально проводити заняття, охопити значний об’єм матеріалу, швидко встановити зворотний зв'язок із студентами; визначити результати засвоєння матеріалу та зосередити увагу на прогалинах у знаннях. Тестовий контроль забезпечує одночасну перевірку знань студентів і формує мотивацію регулярно готуватися до кожного заняття, дисциплінує їх. Крім вищезазначеного, до вагомих переваг тестового контролю потрібно віднести об’єктивність та справедливість оцінки знань, які зменшують емоційні перевантаження студентів, забезпечують прозорість і відкритість результатів контролю, розвивають індивідуально-диференційований підхід до навчання та самостійної роботи студентів [4]. На кафедрі гістології та ембріології запроваджено проведення тестового контролю на кожному практичному занятті, який дозволяє визначити рівень підготовки студентів.

У процесі заняття в усній формі обговорюються складні теоретичні питання. Постійне вдосконалення професійної майстерності викладача, використання ним у навчальному процесі різноманітних, випробуваних часом, новітніх форм і методів викладання дозволяють викладачу на кафедрі гістології та ембріології відмінно вирішувати сучасні завдання $з$ підготовки спеціалістів із числа іноземних громадян.

Висновки. Таким чином, система тестів дозволяє швидко оцінити рівень знань студентів на занятті за короткий термін часу, перейти до виконання практичної роботи. Тестова перевірка знань - вдала форма закріплення, осмислення, систематизації матеріалу. 


\section{Список літератури}

1. Білик Я. С. Психологія мотивації та готовності студентів до професійної діяльності в інноваційному середовищі / Я. С. Білик, А. М. Гулевич // Сучасні методичні технології керування навчальним процесом у вищих медичних навчальних закладах : тези доп. навч.метод. конф. (Вінниця, 15 лют. 2018 р.). - Вінниця, 2018. - С. 10-11.

2. Гуменна А. В. Особливості викладання мікробіології іноземним студентам українською мовою / А. В. Гу-

\section{References}

1. Bilyk, Ya.S., \& Hulevych, A.M. (2018). Psykholohiia motyvatsii ta hotovnosti studentiv do profesiinoi diialnosti v innovatsiinomu seredovyshchi [Psychology of motivation and readiness of students for professional activity in an innovative environment]. Abstracts of the methodological conference of Vinnytsia: "Suchasni metodychni tekhnolohii keruvannia navchalnym procesom u vyshchykh medychnykh navchalnykh zakladakh"- "Modern methodical technologies of management of educational process in higher medical educational institutions" (pp. 10-11) [in Ukrainian].

2. Humenna, A.V., Blinder, O.O., \& Rotar, D.V. (2016). Osoblyvosti vykladannia mikrobiolohii inozemnym studentam ukrainskoiu movoiu [Features of teaching

Електронна адреса для листування: anna.kondaurova@gmail.com менна, О. О. Бліндер, Д. В. Ротар // Актуальная инфектология. - 2016. - № 3 (12).

3. Тригуб Г. Я. Тестирование как метод обучения и контроля знаний в вузе / Г. Я. Тригуб // Научно-методический электронный журнал “Концепт”. - 2017. - № S3. C. 66-68. - URL : http://e-koncept.ru/2017/470051.htm.

4. Григорьева А. И. Перспективный подход к тестированию знаний и тестов / А. И. Григорьева, М.Ю.Колодин // Дистанционное и виртуальное обучение. - 2011. № 10. - С. 84-91.

microbiology to foreign students in Ukrainian]. Aktualnaya infektologiya - Actual Infectology, 3 (12) [in Ukrainian].

3. Trigub, G.Ya. (2017). Testirovanie kak metod obucheniya i kontrolya znaniy $\mathrm{v}$ vuze [Testing as a method of training and knowledge control in high school]. Nauchnometodicheskiy elektronnyy zhurnal "Kontsept" - Scientific and Methodical Electronic Journal “Concept”, S3, 66-68. Retrieved from: http://e-koncept.ru/2017/470051.htm [in Russian].

4. Grigoreva,A.I., \& Kolodin, M.Yu. (2011). Perspektyvnyy podhod k testirovaniyu znaniy i testov [Perspective approach to testing knowledge and tests]. Distantsionnoye i virtualnoye obuchenie - Distance and Virtual Learning, 10, 84-91 [in Russian].

Отримано 11.12.18 